OPEN ACCESS

Citation: González-Durán JA, Plaza RV, Luna L, Arbeláez MP, Deviaene M, Keynan U, Rueda AV, Marín D. Delayed HIV treatment, barriers in access to care and mortality in tuberculosis/HIV co-infected patients in Cali, Colombia. Colomb Méd (Cali), 2021; 52(3):e2024875 http://doi. org/10.25100/cm.v52i4.4875

Received: 05 May 2021

Revised: 29 Nov 2021

Accepted : 06 Dec 2021

Published: 08 Dec 2021

Keywords:

Tuberculosis, HIV, mortality, cohort study, health services accessibility

Palabras clave:

Tuberculosis, VIH, mortalidad, estudio de cohorte, accesibilidad a los servicios de salud

Copyright: @ 2021 Universidad del Valle

(c) (1) -(

ORIGINALARTICLE

\title{
Delayed HIV treatment, barriers in access to care and mortality in tuberculosis/HIV co-infected patients in Cali, Colombia
}

\section{Retraso en el tratamiento para VIH, barreras en el acceso a la atención en salud y mortalidad en personas coinfectadas con tuberculosis y VIH en Cali, Colombia}

\author{
Jorge A González-Duran, ${ }^{1}$ Regina V Plaza, ${ }^{2}$ Lucy Luna, ${ }^{1}$ Maria Patricia Arbeláez, ${ }^{3}$ Meagan \\ Deviaene, ${ }^{4}$ Yoav Keynan, ${ }^{4}$ Zulma Vanessa Rueda, ${ }^{4}$ Diana Marin ${ }^{5}$ \\ dianamarcela.marin@upb.edu.co \\ 1 Secretaría de Salud de Cali, Programa de tuberculosis, Cali, Colombia, 2 Universidad del Cauca, \\ Facultad de Ciencias de la Salud, Popayán, 3 Universidad de Antioquia, Facultad Nacional de Salud \\ Pública, Medellín, Colombia, 4 University of Manitoba, Department of Medical Microbiology and \\ Infectious Diseases, Winnipeg, Manitoba, Canada, 5 Universidad Pontificia Bolivariana, School of \\ Medicine, Medellín, Colombia
}

\section{Abstract}

\section{Objective:}

To determine factors associated with mortality in tuberculosis/HIV co-infected patients in Cali, Colombia

\section{Methods:}

This retrospective cohort design included tuberculosis/HIV co-infected persons. Kaplan-Meier and Cox regression were used to estimate survival and risk factors associated with mortality.

\section{Results:}

Of the 279 tuberculosis/HIV co-infected participants, $27.2 \%$ died during the study. Participants mainly were adults and males. CD4 count information was available for $41.6 \%$ (the median count was 83 cells $/ \mathrm{mm} 3$ ), and half were subject to tuberculosis susceptibility testing. The median time between HIV diagnosis and antiretroviral therapy initiation was 372 days. HIV was identified prior to tuberculosis in $53 \%$ and concurrent HIV-tuberculosis were diagnosed in $37 \%$ of patients. $44.8 \%$ had tuberculosis treatment success. Body mass index above $18 \mathrm{~kg} / \mathrm{m} 2$, initiation of tuberculosis treatment within two weeks, having any health insurance coverage and CD4 count information conferred a survival advantage.

\section{Conclusions:}

Delays in treatment initiation and factors associated with limited health care access or utilization were associated with mortality. As HIV and tuberculosis are both reportable conditions in Colombia, strategies should be focused on optimizing treatment outcomes within both tuberculosis and HIV programs, particularly improving early HIV diagnosis, early antiretroviral therapy treatment initiation, and adherence to tuberculosis treatment. 


\section{Conflicts of interest:}

None to declare.

\section{Funding:}

The Global Fund funded the SORT IT program to Fight AIDS, Tuberculosis, and Malaria through the Tuberculosis project that the Tuberculosis Group of the Country Coordinating Mechanism for Colombia (MCP) presented to The Global Fund in the tenth round. Specifically, this activity was approved as a strategy of sustainability and closure of the project in territories that were prioritized by high burden of tuberculosis in Colombia. The funding agencies did not play any role in the design of the study, the compilation and analysis of the data, the decision to publish or the elaboration of the article.

\section{Disclaimer:}

Authors hold sole responsibility for the views expressed in the manuscript, which may not necessarily reflect the opinion or policy of the author's affiliation or the Pan American Health Organization (PAHO).

\section{Corresponding author:}

Diana Marín. E-mail: dianamarcela. marin@upb.edu.co

\section{Resumen}

\section{Objetivo:}

Determinar factores asociados con mortalidad en personas con co-infeccion Tuberculosis/VIH en Cali, Colombia.

\section{Métodos:}

Este diseño de cohorte retrospectiva incluyó personas co-infectadas con tuberculosis NIH. Se utilizó Kaplan Meier y regresion de Cox para estimar supervivencia y factores de riesgo asociados con mortalidad.

\section{Resultados:}

De los 279 participantes coinfectados con tuberculosis/VIH, el $27.2 \%$ falleció durante el estudio. Los participantes fueron principalmente adultos y hombres. Se dispuso de información de recuento de CD4 en el $41.6 \%$ (la mediana del recuento fue 83 células $/ \mathrm{mm} 3$ ), y en la mitad se realizaron pruebas de susceptibilidad para tuberculosis. La mediana de tiempo entre el diagnóstico de VIH e inicio de terapia antirretroviral fue 372 días. Se identificó VIH previo a tuberculosis en un $53 \%$, e infección concurrente tuberculosis- $\mathrm{VIH}$ en el $37 \%$ de los pacientes. El $44.8 \%$ presentó éxito en el tratamiento para tuberculosis. Un índice de masa corporal superior a $18 \mathrm{~kg} / \mathrm{m} 2$, inicio del tratamiento para TB dentro de las primeras dos semanas, contar con aseguramiento en salud y con recuento de CD4 se asociaron con mayor supervivencia.

\section{Conclusiones:}

Retraso en el inicio de tratamiento y factores relacionados con brechas en el acceso a atención en salud se asociaron con mortalidad. Dado que $\mathrm{VIH}$ y tuberculosis son enfermedades de notificación obligatoria en Colombia, las estrategias deben centrarse en optimizar los desenlaces del tratamiento dentro de ambos programas, en particular mejorar el diagnóstico temprano de $\mathrm{VIH}$, el inicio temprano de la terapia antirretroviral y fomentar la adherencia al tratamiento para tuberculosis.

\section{Remark}

\section{1) Why was this study conducted?}

To describe outcomes of TB treatment among people living with HIV in Cali, Colombia to identify drivers behind poor treatment outcomes that can guide programmatic changes.

\section{2) What were the most relevant results of the study?}

Over a third of patients had HIV diagnosed at the same time as TB; HIV treatment initiation is delayed contributing to poor treatment outcomes; less than half of HIV infected individuals had CD4 cell counts; TB treatment success rate was less than $50 \%$.

\section{3) What do these results contribute?}

Integration of HIV and TB programs with earlier access to antiretroviral therapy could improve treatment outcomes in patients coinfected with HIV and TB. 


\section{Introduction}

In 2020, the global HIV infection prevalence was 37.7 million cases, and there were 9.9 million (95\% uncertainty interval: 8.9 - 11 million) new tuberculosis (TB) cases ${ }^{1,2}$. HIV infection remains one of the most significant risk factors for active $\mathrm{TB}$, with $8 \%$ of new TB infections occurring in people living with HIV in $2020^{2}$. Furthermore, of the TB incident cases over that time, there were 214,000 deaths among people living with HIV, making TB the single most common infectious cause of mortality among people living with HIV ${ }^{1,2}$. Thus, in regions where the prevalence of TB latency is high, preventing HIV infections is an important component of strategies to prevent TB disease.

This has led to the search for factors associated with mortality in HIV/TB co-infection. Among sociodemographic characteristics previously found to be associated with mortality are age group 35 to 44 years, late-onset or non-initiation of antiretroviral therapy, lack of drug susceptibility testing, low CD4 cell count, low body mass index, and absence of concomitant cotrimoxazole therapy ${ }^{3-6}$. Mortality can also be associated with resistant TB strains and the presence of extrapulmonary dissemination or lymph node TB.

In Colombia, from the year 2013 onward, HIV infection in TB cases has been greater than $10 \%{ }^{7}$. In 2014, TB ranked first as the underlying cause of mortality among people living with HIV-AIDS. In 2016, 2,089 cases of TB-HIV co-infection were reported among 13,871 cases of TB, and HIV seropositivity among people diagnosed with active TB reached $15 \%$. Approximately $86.5 \%$ of patients diagnosed with TB had an HIV test result ${ }^{8}$. In Cali during 2014 and 2016, 1,041 and 1,117 cases -all forms- were reported to the Public Health Surveillance System (SIVIGILA), respectively. Among them, the proportion of TB/HIV coinfected cases ranged between $14 \%$ to $17 \%$, of whom $59 \%$ were on cotrimoxazole and $53 \%$ were on antiretroviral therapy ${ }^{9}$.

Colombia faces particular challenges that have been documented in studies conducted in various regions. One key challenge is the low proportion of successful treatment outcomes. National reports do not publish programmatic outcomes, but studies documented treatment success rates ranging from $61 \%$ to $73 \%{ }^{10}$. The WHO Global TB report measures successful general treatment but does not disaggregate data for high-risk groups such as people living with HIV. A study from Medellin, Colombia, showed the dramatic differences in successful treatment between people living with HIV (stratified additionally by being homeless or not) compared to those without HIV $\left(29.7 \%, 62.6 \%, 80.7 \%\right.$, respectively) ${ }^{11}$, highlighting the importance of understanding the epidemiology and risk factors associated unsuccessful treatment for each high-risk group.

The TB/HIV collaborative activities policy promoted by WHO describes activities aimed at lowering mortality attributed to co-infection. Some of these activities include integrating TB and HIV programs, increasing surveillance and active case finding and delivering treatment for active and latent TB ${ }^{12}$. However, although some programs carried out by Health Benefit Plan Providers are adopting this policy in the municipality of Cali, it is difficult to measure the progress, reach, and impact of the integration of TB and HIV programs.

This study aimed to identify factors associated with mortality in those with HIV-TB coinfection in Cali, Colombia.

\section{Materials and Methods}

\section{Design and population}

A retrospective cohort study was undertaken. We included all participants with TB/HIV coinfection that initiated TB treatment between 2014 and 2016.

\section{Municipal tuberculosis program}

The public health office in Cali carries out surveillance activities on TB/HIV co-infection cases following TB and HIV National Programs guidelines. Both diseases require mandatory reporting to Colombia's National Public Health Surveillance System (SIVIGILA, by the Spanish 
acronym). The Government provides diagnosis and treatment and both are carried out at private and public institutions. Public entities provided treatment through five government care institutions, "Empresa social del Estado" (ESE, Spanish language acronym), which offer a service network characterized by one referral hospital and peripheral health centers that manage TB programs.

\section{Data source and variables}

The following variables were collected from the TB program database: sex, age, population group (displaced, disabled, substance user, incarcerated or others), ethnicity (Afro-Colombian, Raizal (population from San Andres Islands), indigenous and others), health benefit plan which includes the following: contributory (apportion of insurance is paid by individual or employer), subsidized (paid as social assistance) or uninsured. Clinical variables: other comorbidities different to TB-HIV, body mass index (BMI) $<18 \mathrm{~kg} / \mathrm{m}^{2}$. TB variables: date and history of previous TB treatment, acid-fast bacilli smear date, type and organ involvement of TB (Pulmonary vs. extrapulmonary TB and affected organ system for the latter), access to drug susceptibility testing, and the result resistant/susceptible if available, and treatment outcome (successful: cured and completed; unsuccessful: lost to follow-up, died or treatment failed) ${ }^{13}$. The date of respiratory symptoms initiation was extracted from the SIVIGILA database.

HIV related variables: the date of HIV diagnosis, date of antiretroviral therapy treatment initiation, information on trimethoprim/sulfamethoxazole prescription (TMP-SMX) (Yes/No), and a CD4 lymphocytes count were extracted from 'High-Cost Account,' a non-governmental technical body that maintains and analyses healthcare data for specific high impact conditions (including HIV, malignancies, etc.).

Antiretroviral therapy treatment initiation delay was defined as therapy start 30 days or more after HIV diagnosis. For delay in the initiation of treatment for TB, we utilized the difference between the start of treatment date and the smear reported result date as a proxy for the date of diagnosis. According to the TB program monitoring and evaluation guideline ${ }^{14}$, two days is considered a delay and two weeks to estimate extended delays.

Deaths reported in SIVIGILA were validated with the national mortality database -DANE(by the Spanish acronym for National Administrative Department of Statistics) until midyear 2017. TB programs seek information regarding mortality during TB treatment in order to attribute the cause of death. During this process, a visit to the person home is conducted and a verbal autopsy performed ${ }^{15}$ by a committee (Unidad de análisis) held jointly with the Healthcare Provider Institution (IPS) and the health insurance company of affiliation where it is concluded whether TB was the cause of death.

\section{Statistical analysis}

Quantitative variables are described with median and interquartile ranges. For survival analysis, the exposure was symptoms onset. The outcome was death; the time variable was the difference between the date of start of TB symptoms until the outcome (mortality) was attained or censored (those alive until June 19, 2017, the date of the last review of the database of deaths of the DANE contrasted with the SIVIGILA). We computed survival curves using Kaplan-Meier. We estimated the crude hazard ratio, the $95 \%$ confidence interval and the two-tailed p-value. A Cox proportional regression analysis to identify factors associated with mortality was performed. Adjusted Hazard Ratio (HR) and the corresponding 95\% confidence interval (CI) were reported. A two-tailed p-value $<0.05$ was considered significant. Analyses were performed on Stata ${ }^{\circledR} \mathrm{SE} 11.1$ and $\mathrm{R}^{\oplus}$ version 3.6.1.

\section{Ethical considerations}

The Ethics Committee at the Universidad Pontificia Bolivariana of Medellín and the Pan American Health Organization (PAHOERC) approved this research. Access to databases received the written approval of the municipal public health office in Cali. This study used secondary information taken from the databases of the TB program of patients diagnosed between 2014 and 2016. It did not involve contact with any participant, and the database was anonymized to protect participants' confidentiality. 


\section{Results}

A total of 279 participants diagnosed with both TB and HIV between 2014 and 2016 were analyzed in the study. Seventy-six of the 279 participants $(27.2 \%)$ died within the 1676 days of study duration. Overall survival in the cohort was more remarkable than $60 \%$, and the mean length of survival was 1226.5 days. Participants were adult primarily, and $79.9 \%$ were male. Except for HIV, the cohort had few comorbidities, and CD4 count information was available for $41.6 \%$ (Table 1). Among those with available CD4, the median count was $83 \mathrm{cells} / \mathrm{mm}^{3}$, and the median time between HIV diagnosis and antiretroviral therapy initiation was 372 days. Thirty-seven percent of individuals received concurrent HIV and TB diagnoses, and 53\% had a previously diagnosed HIV infection. Only one patient received latent tuberculosis infection treatment among those with a prior diagnosis of HIV.

Most TB infections were classified as pulmonary, and approximately half were subject to susceptibility testing by culture, which revealed less than $2 \%$ of first-line resistant infections within this cohort. Less than half $(44.8 \%)$ of the participants had treatment success (Table 2 ).

In bivariate analysis, receiving antiretroviral therapy, a body mass index above $18 \mathrm{~kg} / \mathrm{m}^{2}$, initiation of TB treatment within two weeks, having any health insurance coverage, and having CD4 count information available conferred a statistically significant survival advantage. TMPSMX conferred a survival advantage that did not attain statistical significance. The participant's age and sex had no effect on survival, as well as being enrolled as a new or previously treated or having a pulmonary as compared to an extrapulmonary TB infection (Figure 1).

In multivariate analysis, all previously significant variables remained significant except for receiving antiretroviral therapy (Figure 2).

Table 1. Sociodemographic and clinical characteristics of people co-infected with TB and HIV in Cali, Colombia, 2014-2016

\begin{tabular}{|c|c|c|c|}
\hline Variables & Categories & Frequency & Percentage (\%) \\
\hline \multirow[t]{4}{*}{ Age in years } & $15-24$ & 24 & 8.6 \\
\hline & $25-49$ & 192 & 68.8 \\
\hline & $50-64$ & 47 & 16.8 \\
\hline & $65+$ & 16 & 5.7 \\
\hline Sex & Female & 56 & 20.1 \\
\hline \multirow[t]{3}{*}{ Ethnicity } & Mixed & 93 & 33.3 \\
\hline & Black, Biracial, Afrocolombian & 28 & 10.0 \\
\hline & Other & 158 & 56.6 \\
\hline \multirow[t]{5}{*}{ Population Group } & Internally Displaced & 2 & 0.7 \\
\hline & Disabled & 1 & 0.4 \\
\hline & Person Using Drugs & 36 & 13.2 \\
\hline & Incarcerated & 14 & 5.1 \\
\hline & Other & 219 & 80.5 \\
\hline \multirow{6}{*}{ Comorbidity } & HIV only & 254 & 91.0 \\
\hline & $\mathrm{BMI}<18 \mathrm{~kg} / \mathrm{m} 2$ & 12 & 4.3 \\
\hline & Diabetes & 1 & 0.4 \\
\hline & Renal Disease & 1 & 0.4 \\
\hline & Liver Disease & 1 & 0.4 \\
\hline & Other & 10 & 3.6 \\
\hline CD4 data available & Yes & 116 & 41.6 \\
\hline Prior HIV treatment before TB diagnosis & Yes & $129^{*}$ & 53.1 \\
\hline Concurrent HIV-TB diagnosis & & 84 & 37.5 \\
\hline Prior TB treatment before HIV diagnosis & & $11^{*}$ & 4.9 \\
\hline Median CD4 count cells/mm3 & & & $89(23-236)$ \\
\hline Median time to antiretroviral therapy initiation after HIV diagnosis (days) & & & $372(62-2146.5)$ \\
\hline Median time to TB treatment initiation after TB dx (days) & & & $6(1-18.5)$ \\
\hline
\end{tabular}

* Data about HIV and or TB treatment before TB or HIV diagnosis was available in 224 out of 279. 
Table 2. Tuberculosis characteristics in people co-infected with HIV in Cali, Colombia, 2014-2016

\begin{tabular}{|c|c|c|c|}
\hline Variables & Categories & Frequency & Percentage (\%) \\
\hline \multirow[t]{10}{*}{ Tuberculosis Subtype } & Pulmonary & 203 & 72.8 \\
\hline & Extrapulmonary & 76 & 27.2 \\
\hline & Lymph node & 25 & 32.9 \\
\hline & Meningeal & 21 & 27.6 \\
\hline & Pleural & 13 & 17.1 \\
\hline & Miliary & 7 & 9.2 \\
\hline & Intestinal & 5 & 6.6 \\
\hline & Peritoneal & 3 & 3.9 \\
\hline & Osteoarticular & 1 & 1.3 \\
\hline & Other & 1 & 1.3 \\
\hline \multirow[t]{3}{*}{ Tuberculosis Antibiotic Susceptibility } & Resistant & 5 & 1.8 \\
\hline & Susceptible & 116 & 41.6 \\
\hline & No Information Available & 158 & 56.6 \\
\hline \multirow[t]{6}{*}{ History of previous TB treatment } & New & 237 & 84.9 \\
\hline & Previously Treated Patients & 42 & 15.1 \\
\hline & Treatment after loss to follow-up & 20 & 47.6 \\
\hline & Relapse & 12 & 28.6 \\
\hline & Transfer (Other) & 9 & 21.4 \\
\hline & Treatment after failure & 1 & 2.4 \\
\hline \multirow[t]{5}{*}{ Programmatic Outcome } & Treatment Success (completed and cured) & 125 & 44.8 \\
\hline & In Treatment & 52 & 18.6 \\
\hline & Died & 49 & 17.6 \\
\hline & Lost to Follow Up & 48 & 17.2 \\
\hline & Treatment Failed & 5 & 1.8 \\
\hline
\end{tabular}

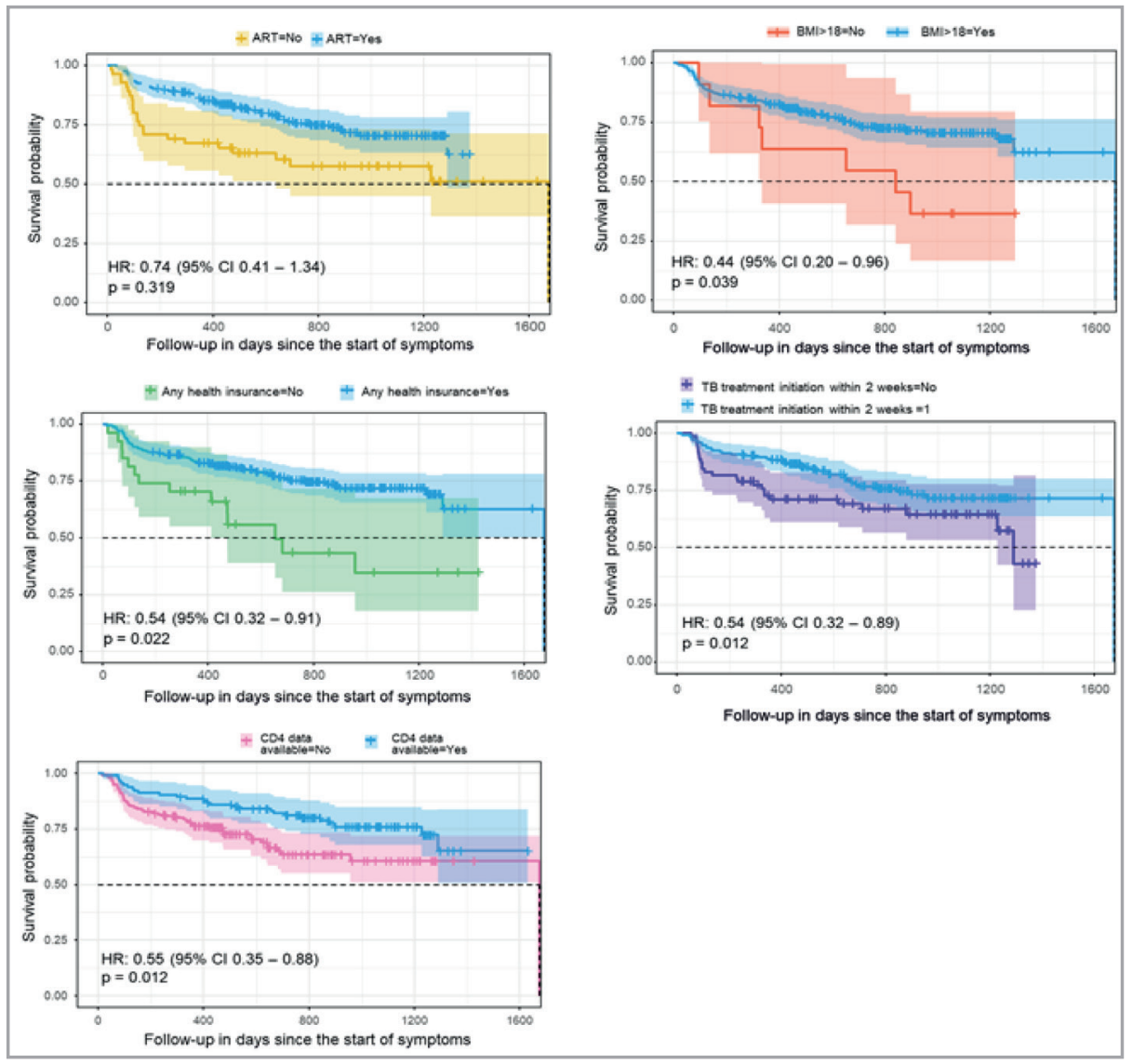

Figure 1. Survival curves in people co-infected with TB and HIV in Cali, Colombia, 2014-2016. The dot lines represent the median. ART: Antiretroviral therapy. BMI: Body mass index in $\mathrm{kg} / \mathrm{m} 2$. Any insurance means that the patient had any form of health insurance with access to health care (either contributive or subsidized) compared to those who did not have-tuberculosis treatment initiation within two weeks after TB diagnosis. 


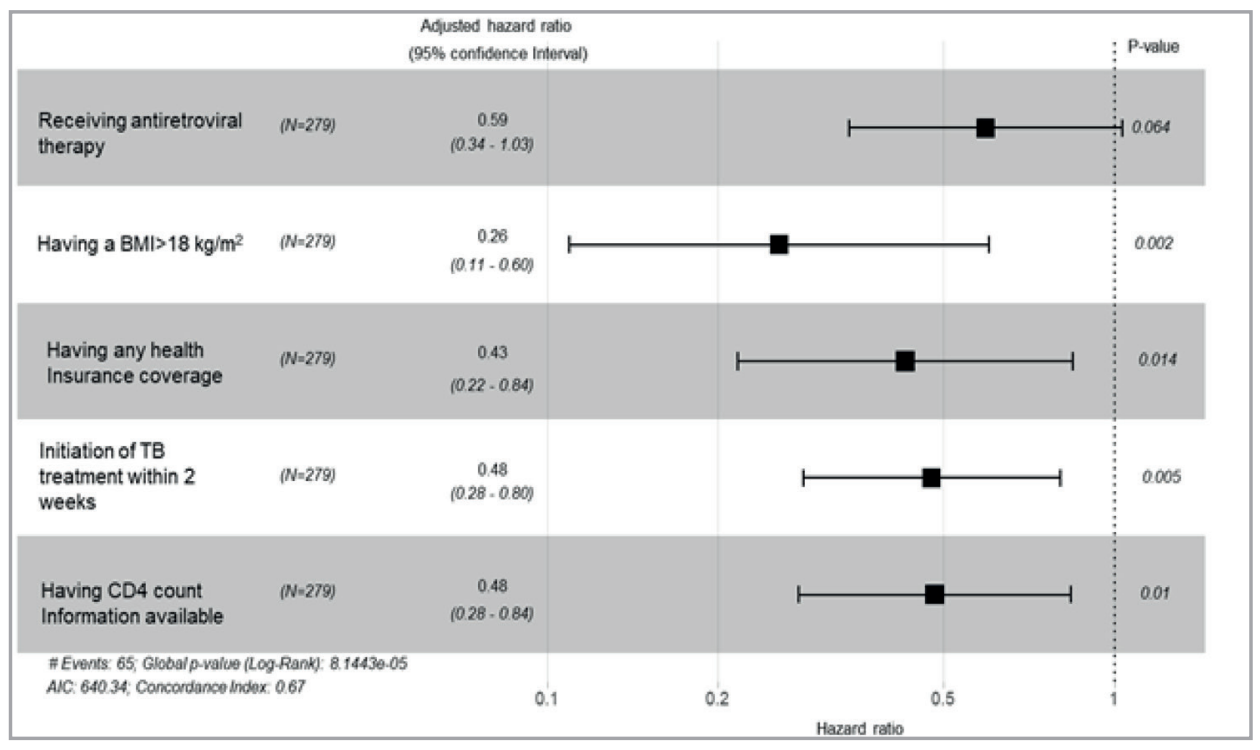

Figure 2. Multivariate analysis. Risk factors associated with mortality in people co-infected with TB and HIV in Cali, Colombia, 2014-2016. BMI: Body mass index in $\mathrm{kg} / \mathrm{m} 2$. Any insurance identifies patients that had any health insurance for access to health care compared to those who did not have-tuberculosis treatment initiation within two weeks after TB diagnosis. $\mathrm{N}$ is the number of patients.

\section{Discussion}

Overall, the main findings from this HIV/TB infected cohort were: i) less than half of the individuals with HIV/TB co-infection had CD4 counts recorded and when available advanced HIV stage with low CD4 was observed. ii) More than half of the patients had a previously diagnosed HIV and 37\% received concurrent HIV and TB diagnoses. iii) TB treatment success rate was very low-less than 50\%. and iv) Having any type of insurance, initiation of TB treatment within two weeks, CD4 information available and BMI $>18 \mathrm{~kg} / \mathrm{m}^{2}$ are found to be protective factors against mortality in HIV-TB co-infected patients. Taken together, this information suggests significant gaps in timely access to care and treatment initiation among people living with HIV who are co-infected with TB. Earlier diagnosis of HIV, access to HIV therapy and consistent screening for TB among HIV-infected individuals are significant existing gaps that should be consistently captured as programmatic performance indicators. Alignment of HIV and TB programs may allow for more timely therapy and potentially better outcomes.

The median CD4 count in this cohort was 83 per cubic millimeter in those with available information representing very advanced HIV disease, and an HIV treatment initiation delay of 372 days illustrates difficulties in access to antiretroviral therapy that is likely a contributor to the observed suboptimal TB treatment outcomes. Receiving antiretroviral therapy as soon as possible after HIV diagnosis is internationally accepted ${ }^{16}$ and has been shown to improve outcomes among HIV/TB co-infected individuals ${ }^{17}$. In our study, the median time to antiretroviral therapy start was one year and this delay, in addition to $37 \%$ with concurrent HIV/TB diagnoses are likely contributed to poor TB treatment outcomes. HIV early diagnosis, CD4 count availability and timely antiretroviral therapy initiation are pillars of functional HIV programs. Therefore, the HIV strategies should focus on early HIV diagnosis and improved access to early antiretroviral therapy treatment to increase the CD4 count at the time of diagnosis. The findings of this study indicate that delayed diagnosis and unacceptable delays in HIV treatment initiation are significant gaps for this program.

Improving testing for TB among HIV-infected individuals has to be emphasized as the risk of developing active TB in HIV-infected individuals with latent tuberculosis infection is very high. latent tuberculosis infection screening among the 53\% of participants with a prior HIV 
diagnosis with only one patient receiving latent tuberculosis infection therapy represents an area where significant improvements are needed as failure to identify MTB infection contributes to poor outcomes. It has been demonstrated and internationally recommended to screen and treat latent tuberculosis infection among HIV-infected individuals ${ }^{18}$; failing to do so is associated with TB transmission and poorer outcomes ${ }^{19}$. In addition, the fact that $37 \%$ of patients had a concurrent diagnosis of HIV and TB with advanced HIV disease presents challenges for managing co-infection and potentially increased opportunities for TB transmission. While TB-HIV co-infection poses its share of challenges to the health care system, a diagnosis of either HIV or TB presents an opportunity for identification and enrollment in the other program, thus optimizing patient care.

The low overall treatment success rate we report for this cohort falls short of the WHO End TB strategy objectives of $90 \%{ }^{20}$. People living with HIV who are co-infected with TB should be a priority for the national and local TB program as the successful treatment was less than $50 \%$, the mortality was higher (17.2\%) than those with TB but uninfected with HIV (10\%) ${ }^{10}$, and $17.2 \%$ were lost to follow up. While WHO has no particular recommended timeline for TB treatment initiation, it is generally accepted that initiation should occur as soon as diagnostic results become available. A delay of 2 days was not associated with decreases in survival within this cohort. However, delays of 2 weeks or longer were associated with decreased survival. This finding suggests that any improvement has the potential to have a considerable effect within this population.

Once TB treatment is prescribed, adherence to TB treatment is important as $17 \%$ of patients were lost to follow-up. HIV and TB are reportable in Colombia, and the WHO policy on collaborative TB/HIV activities, recommends integrating TB and HIV services to improve access to care and decrease delays in this key population can be considered ${ }^{12}$. Individuals that are lost to follow up, in addition to delaying in antiretroviral therapy treatment initiation, suggest that there may be barriers to health care uptake, which may be associated with other social determinants, such as poverty, homelessness and addictions leading to the decreased seeking of health care and posing difficulties in transportation to health care centers. This association was previously reported in studies from other regions of Colombia ${ }^{11}$.

On the other hand, having any form of insurance was found to be protective for mortality in TB/HIV co-infected population and it appeared to be related to improved survival and a determinant for improved health care access. Oxlade et al. ${ }^{(21}$, found that general increases in health care services were linked to decreases in TB mortality, even when not linked to TB alone. Social determinants of health play a role in HIV and TB acquisition, with those who are more socially disadvantaged (for example, having low socioeconomic status, marginalization, and social exclusion) carrying a more considerable disease burden ${ }^{22}$. A previous study has found that being uninsured is linked to poverty and is associated with decreases in health care use in the United States and globally ${ }^{23-25}$, general social programs aimed at increasing social capital among marginalized groups, thus, may decrease morbidity and mortality of this coinfection and instill trust in social systems, potentially increasing health care utilization.

Finally, low nutrition status was linked to mortality in this population and it can be explained as a low BMI may be a consequence of advanced HIV, TB, or both and serves as an indicator for late access to therapy. For example, a Senegal pilot study found that those receiving nutrition support all completed TB treatment and had resultant negative smears ${ }^{26}$. In addition, supporting nutrition may lead to improved treatment outcomes by directly improving health or by diverting money that would otherwise be spent on food to other health care costs ${ }^{27}$.

Factors not associated with a survival advantage include organ involvement- pulmonary as compared to extrapulmonary TB. In addition, TB meningitis was associated with a worse survival outcome than any other infection site. TMP-SMX administration has been previously reported to confer a survival advantage for those with HIV-TB co-infection ${ }^{28,29}$, however, this finding was 
not replicated in this study. This could potentially be due to a modification of healthcare-seeking behaviors in those already receiving prophylactic against opportunistic infections or may be attributed to the low CD4 count that dictates initiation of TMP/SMX in the first place.

Limitations of this study include the incompleteness of information regarding the HIV disease status of the participants. Although this is a limitation for any study using secondary information, the use of data from the surveillance system is very a practical approach for healthcare authorities to identify gaps and protective factors that allow allocation of resources to improve programmatic outcomes. Another limitation is that these data, by definition, represent those captured by the health care system and may not reflect those who did not access health care at all and thus may underestimate the gaps in care provision.

\section{Conclusions}

Factors associated with health care utilization were associated with mortality; therefore, interventions that promote uptake of health care seem to be called for within this population. The low CD4 count at the time of TB diagnosis is striking and carries worse outcomes, together with limited availability of $\mathrm{CD} 4$ and extensive delays in antiretroviral therapy initiation are all findings that underscore deficiencies in HIV programming. As HIV and TB are both reportable conditions in Colombia, opportunities for integrated strategies focused on optimizing treatment outcomes within each of the TB and HIV programs, particularly improving early HIV diagnosis, latent TB screening among HIV infected, early antiretroviral therapy treatment initiation, and increasing adherence to TB treatment should be explored.

\section{References}

1. UNAIDS. Global HIV \& AIDS statistics - Fact sheet. UNAIDS; 2021. Cited: 2021 Nov 24. Available from: https://www.unaids.org/en/resources/fact-sheet

2. World Health Organization. Global tuberculosis report 2021. WHO; 2021. Cited: 2021 Nov 29. Available from: https://www.who.int/teams/global-tuberculosis-programme/tb-reports

3. Maponga BA, Chirundu D, Gombe NT, Tshimanga M, Bangure D, Takundwa L. Delayed initiation of antiretroviral therapy in TB/HIV co-infected patients, Sanyati District, Zimbabwe, 2011-2012. Pan Afr Med J. 2015; 21:1-6: doi: 10.11604/pamj.2015.21.28.5195 [PubMed]

4. Manosuthi W, Wiboonchutikul S, Sungkanuparph S. Integrated therapy for HIV and tuberculosis. AIDS Res Ther. 2016;13:22: doi: 10.1186/s12981-016-0106-y [PubMed]

5. Gesesew H, Tsehayneh B, Massa D, Gebremedhin A, Kahsay H, Mwanri L. Predictors of mortality in a cohort of tuberculosis/HIV co-infected patients in Southwest Ethiopia. Infect Dis Poverty. 2016; 5:1-9: doi: 10.1186/ s40249-016-0202-1 [PubMed]

6. Podlekareva DN, Efsen AMW, Schultze A, Post FA, Skrahina AM, Panteleev A, et al. Tuberculosis-related mortality in people living with HIV in Europe and Latin America: an international cohort study. Lancet HIV. 2016; 3(3): e120-31. 10.1016/S2352-3018(15)00252-0 [PubMed]

7. Instituto Nacional de Salud. Vigilancia centinela de VIH en personas con tuberculosis en Barranquilla, Bucaramanga, Medellín y Cali, 2009 - 2010. 1. ed. Bogotá: Instituto Nacional de Salud; 2011. 56 p.

8. Ministerio de Salud y Protección Social. Evaluación de la implementación de los planes nacionales de respuesta ante ITS-VIH/SIDA, acciones colaborativas TB-VIH, hepatitis virales, 2014-2017. Ministerio de Salud y Protección Social; 2018. Available from: https://www.minsalud.gov.co/sites/rid/Lists/BibliotecaDigital/RIDE/VS/ PP/ET/evaluacion-implementacion-planes-nal-vih. 
Delayed HIV treatment, barriers in access to care and mortality in tuberculosis/HIV co-infected patients in Cali, Colombia.

9. Lesmes M, Reina L. Informe anual 2017. Vigilancia en salud pública. Gobernación Valle del Cauca. 2017. Available from: https://www.valledelcauca.gov.co/loader.php?IServicio=Tools2\&ITipo=viewpdf\&id=545file://C:/ Users/USUARIO/Downloads/Boletin\%20epidemiologico\%202016-\%20dic15-2017\%20(1).pdf

10. WHO. WHO Tuberculosis Treatment Outcomes. Data provided by countries for the Global Tuberculosis Report. WHO; 2017. Available from: http://www.who.int/tb/country/data/download/en/

11. Gómez LM, Paniagua-Saldarriaga LA, Richert Q, Keynan Y, Montes F, López L, et al. Homelessness and HIV: A combination predictive of poor tuberculosis treatment outcomes and in need of innovative strategies to improve treatment completion. Am J Trop Med Hyg. 2019; 100(4): 932-9: doi: 10.4269/ajtmh.18-0305 [PubMed]

12. OMS. Política de la OMS sobre actividades de colaboración TB/VIH. Guía para programas nacionales y otros interesados directos. WHO; 2012. Cited: 2019 Oct 8. Available from: https://apps.who.int/iris/bitstream/handle/10665/44838/9789243503004_spa. pdf;jsessionid=0F11C9E38EDDEFB3796401155ACA1CF9?sequence=1

13. World Health Organization. WHO Definitions and reporting framework for tuberculosis. WHO; 2013. Cited 2018 Mar 19. Available from: https://apps.who.int/iris/handle/10665/79199

14. OIM, Instituto Nacional de Salud, Ministerio de Salud y Protección Social. Plan de Monitoreo y Evaluación. Programa Nacional de Prevención y Control de la Tuberculosis. Ministerio de Salud y Protección Social; 2017. Cited 2019 Oct 6. Available from: https://www.minsalud.gov.co/sites/rid/Lists/BibliotecaDigital/RIDE/VS/PP/ET/ plan-monitoreo-evaluacion-tuberculosis.pdf

15. WHO. WHO Verbal autopsy standards: ascertaining and attributing causes of death. WHO; 2016. Cited 2019 Oct 6. Available from: http://www.who.int/healthinfo/statistics/verbalautopsystandards/en/

16. WHO. Guidelines for managing advanced HIV disease and rapid initiation of antiretroviral therapy. WHO; 2017. Cited 2017 Dec 26. Available from: http://www.who.int/hiv/pub/guidelines/advanced-HIV-disease/en/

17. INSIGHT START Study Group, Lundgren JD, Babiker AG, Gordin F, Emery S, Grund B, et al. Initiation of Antiretroviral Therapy in Early Asymptomatic HIV Infection. N Engl J Med. 2015; 373(9): 795-807: doi: 10.1056/ NEJMoa1506816 [PubMed]

18. World Health Organization. Guidelines for intensifid tuberculosis case- finding and isoniazid preventive therapy for people living with HIV in resource- constrained settings. WHO; 2011. Cited 2017 Dec 21]. Available from: http://apps.who.int/iris/bitstream/10665/44472/1/9789241500708_eng.pdf.

19. Golub J, Saraceni V, Cavalcante S, Pacheco A, Moulton L, King B, et al. The impact of antiretroviral therapy and isoniazid preventive therapy on tuberculosis incidence in HIV-infected patients in Rio de Janeiro, Brazil. AIDS. 2007; 21(11) :1441-8: doi: 10.1097/QAD.0b013e328216f441 [PubMed]

20. WHO. WHO The End TB Strategy. WHO; 2021. Cited 2021 Oct 27. Available from: http://www.who.int/tb/ strategy/en/

21. Oxlade O, Schwartzman K, Behr MA, Benedetti A, Pai M, Heymann J, et al. Global tuberculosis trends: a reflection of changes in tuberculosis control or in population health?. Int J Tuberc Lung Dis. 2009; 13(10):123846 [PubMed]

22. Raviglione M, Sulis G. Tuberculosis 2015: burden, challenges and strategy for control and elimination. Infect Dis Rep. 2016; 8(2): 33-37. Doi: 10.4081/idr.2016.6570

23. Umeh C, Feeley F. Inequitable access to health care by the poor in community-based health insurance programs: a review of studies from low- and middle-income countries. Glob Health Sci Pr. 2017; 5(2): 299-314: doi: 10.9745/GHSP-D-16-00286 
24. Nguyen $\mathrm{KH}$, Sommers $\mathrm{BD}$. Access and quality of care by insurance type for low-income adults before the affordable care act. Am J Public Health. 2016; 106(8): 1409-15: doi: 10.2105/AJPH.2016.303156. [PubMed]

25. Srivastava D, McGuire A. Patient access to health care and medicines across low-income countries. Soc Sci Med. 2015; 133: 21-7: doi: 10.1016/j.socscimed.2015.03.021. [PubMed]

26. Benzekri NA, Sambou JF, Tamba IT, Diatta JP, Sall I, Cisse O, et al. Nutrition support for HIV-TB co-infected adults in Senegal, West Africa: A randomized pilot implementation study. PloS One. 2019; 14(7): e0219118: doi: 10.1371/journal.pone.0219118 [PubMed]

27. Zachariah R, Spielmann MP, Harries AD, Salaniponi FML. Moderate to severe malnutrition in patients with tuberculosis is a risk factor associated with early death. Trans R Soc Trop Med Hyg. 2002; 96(3): 291-4: doi: 10.1016/s0035-9203(02)90103-3 [PubMed]

28. Essomba NE, Ngaba PG, Halle MP, Afane-Voundi Y, Coppieters Y. Risk factors for mortality in patients with tuberculosis and HIV in Douala (Cameroon). Med Sante Trop. 2017; 27(3): 286-91: doi: 10.1684/mst.2017.0713 [PubMed]

29. Varma JK, Nateniyom S, Akksilp S, Mankatittham W, Sirinak C, Sattayawuthipong W, et al. HIV care and treatment factors associated with improved survival during TB treatment in Thailand: an observational study. BMC Infect Dis. 2009; 9(1): 42: doi: 10.1186/1471-2334-9-42 [PubMed] 